\title{
LEXICAL AND STYLISTIC PECULIARITIES OF AMERICAN POLITICAL NEWS DURING 2019-2020 YEARS
}

\section{Mosiyevych L. V.}

\section{INTRODUCTION}

Today, politics is one of the most influential factors in society, its role is constantly growing. The system of mechanisms and technologies of political communication operates in political discourse, and political news in particular. To avoid manipulation of public consciousness during political communication it is necessary to study and analyze these processes to be able to recognize the linguistic mechanisms that contribute to the impact on the recipient ${ }^{1}$. On the one hand, the political news is distinguished by an official style, but, on the other hand, in our study we sorted out a lot of informal words, phraseological units etc. That fact can be explained by multifunctional character of political discourse. To achieve goals, the politicians have to solve political issues with the help of language. Lexical means can perform not only informative, but evaluative and manipulation functions as well. The scientists pay much attention to political linguistics which has become quite relevant on the multidimensional world arena (P. Chilton ${ }^{2}$, T. Dijk, J. Charteris-Black ${ }^{3}$ etc.).

Therefore, the aim of our study is to examine the lexical and stylistic peculiarities of political communication in American news during 20192020 years. The data for analysis are taken from American sites CNN News, The New York Times. We sorted out the most relevant thematic groups (Impeachment, the USA foreign policy, Migrants, Elections, COVID-19) and analyzed their verbalization. The high nominative density of verbalization means in these thematic clusters proves the conceptual relevance of the problems they represent.

The American news is characterized with a great variety of different lexical peculiarities. The article studies the use of informal words,

${ }^{1}$ Dijk T. Discourse and manipulation. Discourse and society. London : SAGE Publications, 2006. P. 359-383. DOI: 10.1177/0957926506060250.

${ }^{2}$ Chilton P. Politics as Text and Talk: Analytic Approaches to Political Discourse. Discourse Approaches to Politics, Society and Culture. Amsterdam, 2002. P. 123-132. DOI: 10.1075/dapsac.4.

${ }^{3}$ Charteris-Black J. Politicians and rhetoric: the persuasive power of metaphor. New York : Palgrave McMillan, 2005. 256 p. DOI: 10.1057/9780230501706. 
euphemisms, neologisms, juridical terms, Americanisms in it. A lot of neologisms are related to Trump and COVID-19. The most productive way of their word-building is blending.

The wide use of juridical terms is caused by the impeachment act. The analysis shows the tendency of prevailing informal words over euphemisms and politically correct words.

The American political news is also characterized by a great deal of stylistic peculiarities (tropes, syntactical stylistic devices, phraseological units).

\section{The most relevant thematic clusters and their verbalization}

The political life in the USA is quite turbulent and its topical current events are: Trump's racist policy, the US-Ukrainian conflict (a telephone conversation about activities of former US Vice President Joe Biden and his son Hunter), the President impeachment, elections and Coronavirus.

We analyzed the verbalization of the thematic groups in American political news and sorted out the following ones:

1. The impeacment of D. Trump: this group is verbalized with such lexical units as impeachment inquiry, impeachment clause, impeachment probe, articles of impeachment, impeachment hearings, Impeachment Trials, impeachment subpoena, impeachment witness, to prompt impeachment, the power to impeach etc. We should say that Trump image is negatively depicted with the lexemes of negative connotation:

...Yovanovitch is crucial to the Democrats' goal of painting a picture of a vain, out-of-control President abusing his power and bypassing established US diplomatic channels [CNN News].

...Conway also slammed Trump as "self-obsessed" and argued that the problem with Donald Trump is, he always sees himself first [CNN News].

...Schiff criticized President Trump at the event, calling him "a charlatan" [CNN News].

...TV offers our tube-addicted President a soothing glow any time of day or night while Twitter gives him something to do with his anxious fingers [CNN News].

D. Trump's attitude to the impeachment is as if it's a performance or a hoax. In his speeches he gives a negative assessment of it using the words: pipe dream, kangaroo court, scam, impeachment hoax:

...And it doesn't matter, because right now you have a kangaroo court headed by little Shifty Schiff, where we don't have lawyers, we don't have witnesses, we don't have anything [CNN News].

....Because it's a scam [CNN News].

It's worth mentioning a high derivative level of the word impeachment that can be used as different parts of speech: When the Framers talked about 
impeachable offenses, they mentioned the President engaging in a corrupt relationship with a foreign power [The New York Times].

...If the House votes to impeach, the few Senate Republicans who might have reservations about Trump's actions with Ukraine could still vote for his acquittal and place the blame on Democrats for tainting the investigation [The New York Times].

... Behold the Lord High Impeacher [CNN News].

2. The USA foreign policy (with Ukraine, Russia, North Korea etc.) is represented with the lexical units: newly heightened strain, weapons development, Seoul's anxiety, missiles, downplayed the launches, missile launches, US-Korea policy program, alliance partner, Trump-Zelensky call transcript, notorious July 25 chat, whistleblower complaint, the July call, US-Ukraine relations, Russian aggression, Russian invasion etc.

To emphasize the danger of the enemy some bookish words can be used: ...In her role as deputy assistant secretary of defense for Russia, Ukraine and Eurasia, Cooper helped orchestrate US strategy for bolstering Ukraine's military, a bulwark against Russia [CNN News]. The word bulwark is formal and means "a strong support or protection".

3. Struggle against migrants: Muslim-majority countries, Islamophobia, microaggressions, Muslimness, to curb migration, asylum officer, asylum applicants, racist agenda, Hispanic and Latino populations, Migrant Protection Protocols program, Shattered Refuge, crisis at the southern border, immigration proceedings, metering policy, President Donald Trump's border wall, "America First" policy etc.

In his speeches Trump emphasizes the fact that migrants are aliens who break the law: mass migration of aliens, unlawful entry, inadmissible aliens etc.

4. Elections: general elections, national elections, parliamentary elections, presidential elections, early elections, snap elections, by elections, midterm elections, direct/indirect elections, free and fair elections, transparent elections, fresh elections, run-up to elections, litmus test, to hold/conduct elections, to cancel elections, to call elections, to schedule elections for, to boycott elections, to postpone elections, to delay elections, to dispute elections.

We have made the comparative analysis of verbalization of Trump's and Biden's personalities: Trump is described with the help of such lexemes or lexical units as coward, to unravel democracy, narcissistic quest, to scheme, fraudulent claims, the worst presidency in history, the damage he has done, his war on science and ethics, huge stress on our democracy, to jeopardize the safety, dictatorial machinations etc.

As we can see all of them have a negative connotation. We can not say that Biden's semantic description abounds in positive lexemes, however, we have found some: clear and commanding victory, superb choice, diverse 
team etc. To our mind that verbalized disbalance shows that the Americans hate Trump more than they love and trust Biden.

5. COVID-19: coronavirus patients, Covid doctors, self-quarantine, selfisolating, protective equipment, vaccine, virus's genome, anti-lockdown rally, Covid-19 pandemic, social distancing measures, asymptomatic cases, infection control measures, the newly confirmed cases, Covid-19 positivity rates, ICU beds, "Covid party", coronavirus hotspot, coronavirus complications, coronavirus outbreak, stay-at-home order, coronavirus death toll.

Thus, the high nominative density of verbalization of these thematic groups proves the conceptual relevance of the problems they represent.

\section{Lexical peculiarities of American political news}

We should note that American news is characterized by such lexical peculiarities as:

1. Informal words. The American people and the politicians as well, tend to emphasize their informal language. That's why even the political discourse abounds in colloquial words which help the officials to make the distance between them and people shorter.

The headline White House beefs up staff to fight impeachment has a colloquial verb to beef up, that means "to increase or improve something, or to make it more interesting".

Let's give the example of one more informal noun - a nail-biter. It was derived from the verb collocation "to bite nails". It got its indirect meaning "dangerous, nervous situation" due to semantic modulation: to bite nails $=$ to be nervous. ...Republicans are happy for the win, but they have to be concerned that an election in a GOP district that Trump won by 12 points in 2016 was such a nail-biter in 2019 [The New York Times].

2. Neologisms. The introduction of a lexical innovation into political texts creates some intellectual tension, because a new word makes a reader guess its possible meaning. It also draws attention to new realia and involves a reader in participation in communication process. The lexical innovations can also perform evaluative function.

Some neologisms are related to D. Trump, all of them have a negative connotation and are mainly built by blending. According to Prof. Yu. Zatsnyi they can be called the telescopy neologisms ${ }^{4}$.

...And if he did, are you satisfied with the idea of Trump transforming our nation from the United States of America into Trumpistan? No, our country would not become Afghanistan [CNN News]. The neologism

4 Зацний Ю.А. Способи та механізми створення лексико-фразеологічних інновацій англійської мови (2009-2019рр.). Нова філологія. Запоріжжя : ЗНУ, 2020. № 79. C. 20-26. DOI: 10.26661/2414-1135/2020-79-04. 
Trumpistan was built by merging the names of the President and the country of Afghanistan.

The neologism Trumpocalypse is built by merging the name of the President and the word apocalypse, which has a negative meaning:

...After 6 months as president Trump has caused the Trumpocalypse everyone was worried about which wrecked the United States as we knew it [CNN News]. This innovation reflects the vision of his coming to the White House as an apocalypse because of his radical, extravagant statements and actions that frightened an American society.

...While the Trump Administration's harsh crackdown on immigrants builds on an enforcement infrastructure inherited from previous administrations, this Article cautions against characterizing it as merely an escalation of "crimmigration" [The New York Times]. The neologism crimmigration is formed by merging the words criminal and immigration and has the meaning "the merging of criminal and immigration law evident in recent decades".

COVID-19 also caused the appearance of some lexical innovations:

...The 2019-CoV outbreak and response has been accompanied by a massive "infodemic" - an over-abundance of information - some accurate and some not - that makes it hard for people to find trustworthy sources and reliable guidance when they need it [The New York Times].

The word infodemic is partially explained in the context, but it has more detailed meaning: "a very large amount of information that is published about a particular problem, some of which is untrue, therefore making it more difficult to find a solution".

One more neologism double bubble means "the people from two separate households who are allowed to see each other as part of the gradual easing of restrictions during the Covid-19 pandemic":

...In particular, social bubbles are a way to support Canadians experiencing mental-health issues due to the loneliness of isolation as well as parents who are desperate for help with childcare. But even if you fall into neither of those groups, a double bubble means some long-awaited social interactions [The New York Times].

The lockdown due to COVID-19 caused the appearance of the neologism phygital (a combination of physical and digital elements to sell and market a product): ...In light of lockdown the idea of 'phygital' strategy is being turned on its head. It's no longer about splicing a digital element into physical experiences. More challenging perhaps, it's now about bringing real physical connection to digital experiences [The New York Times].

3. Euphemisms. The political texts are distinguished by a great number of euphemisms which create some false reality due to the effect of blurring, 
ambiguity $^{5}$. These lexical units can influence the formation process of worldview of a great number of people. They can also deceive and neutralize the critical mind of a person. The euphemisms are the ideal means for manipulation of people because they hide the real essence of the matter due to creation of neutral or positive connotation ${ }^{6}$.

With the help of political euphemisms the level of negative valuation becomes smaller, hence one can speak about the complete change of pragmatic focus. The political news is supposed to abound in euphemisms. However, the analysis showed the American politicians do not tend to veil their remarks especially negative ones. Nevertheless, there are some euphemisms in American news: ...He praised President Recep Tayyip Erdogan, hinted that the Turkish leader would soon visit Washington and appeared to wash his hands of further US involvement in Syria [CNN News]. The political euphemisms involvement, intervention, operations are the synonyms for the word invasion, if it is about the military actions on the other's country territory.

In October 2019 the leader of Islamic state was murdered by the US-troops in Syria: ...In a statement, former Vice President Joe Biden congratulated "our special forces, our intelligence community, and all our brave military professionals on delivering justice" to Baghdadi [CNN News]. The euphemism delivering justice veils the concept murder.

4. Juridical terms. The analysis of our material showed that a great deal of terms which can be seen in American news is related to law. It proves that politics conceptually depends on law, especially in the light of impeachment events:

...Republicans downplayed the significance of Holmes' testimony to the Democrats' case for impeachment [CNN News].

...The White House has filed a memo opposing CNN's suit against the Trump administration, saying no journalist has a constitutional right to access [CNN News].

Speaking about the word-formation peculiarities of the US political news, we singled out conversion and determinologization (migration of terms outside their terminological systems ${ }^{7}$ ):

...Holmes said he was supposed to be a note-taker for the meeting, but when he arrived he was told by an aide to Yermak that they wanted a one-

5 Holder R.W. Dictionary of euphemisms. Oxford : Oxford University Press, 2008. $501 \mathrm{p}$.

${ }^{6}$ Mosiyevych L. The Formation of a Modern Translation Competence in Translator Training. At the Crossroads: Challenges of Foreign Language Learning. 2017. April. P. 189-203. DOI: 10.1007/978-3-319-55155-5.

7 Зацний Ю.А. Сучасний англомовний світ і збагачення словникового складу. Львів : ПАІС, 2007. 228 с. 
on-one meeting with "no note-taker". The noun note-taker is formed from the verbal phrase to take notes [CNN News].

...Democratic donors, watching Biden struggle to break out in the crowded field and liberals like Warren and Sanders pick up momentum, have been whispering for weeks that other Democrats should consider shaking up the race [CNN News]. In this sentence the medical term donor can be used in the meaning of sponsor.

The music term staccato can be used in the juridical context: ...After listening to hours of staccato testimony from Robert Mueller, the man whose job it was to answer difficult questions, the country is left with yet another unknown [CNN News].

5. Americanisms. The differences between American English and British English become apparent in political news. They are mainly revealed in the form of Americanisms - words or phrases used in $\mathrm{AmE}^{8}$ :

... After drum lines, chants, gaggles and forums at the recent Polk County Steak Fry, the 2020 Democratic hopefuls are now setting their sights on the first milestone of the presidential marathon - February's Iowa caucuses [CNN News]. Caucus is a typical americanism having a meaning "a group of politicians within a political party who have special interests". We should note that there are some derivatives from it: ...He also performs about the same with previous caucusgoers as first-timers [CNN News].

The Americanism "shakedown" means "a situation in which someone uses threats to force someone else to give them money": "Nothing says I love you like a shakedown", said Vipin Narang, an associate professor at MIT who follows the Korean peninsula, summarizing South Korean uncertainty about the US [CNN News].

The next Americanism has a stylistic remark "informal" and means "silly or impossible to understand": ...This cockamamie notion, which has no basis in fact, connects Kiev with Hillary Clinton and the Democratic Party and removes the stain from Trump's election victory [CNN News].

The members of the staff of an organization are called staffers in AmE: The former vice-president and incoming president is yet to announce his picks for various major cabinet agencies, but he has unveiled a big portion of his senior staff so far, and that batch of incoming top staffers are largely the gang of advisers Biden has kept close to him for years [CNN News].

Thus, the results of lexical peculiarities of American news are represented in table 1 .

\footnotetext{
8 Ларцева Е.В. Современный статус американского варианта английского языка и перспективы его развития. Актуальные проблемы германистики, романистики и русистики : материалы ежегодной международной конференции, г. Екатеринбург, 3-4 февраля 2012 г. : в 2 ч. Екатеринбург, 2012. Ч. 1. С. 83-90.
} 
Table 1

Lexical peculiarities of American news (during 2019-2020 years) and their quantitative indicators

\begin{tabular}{|c|c|}
\hline Lexical peculiarities & Quantitative indicators \\
\hline Informal words & $30 \%$ \\
\hline Neologisms & $12 \%$ \\
\hline Juridical terms & $23 \%$ \\
\hline Euphemisms & $20 \%$ \\
\hline Americanisms & $15 \%$ \\
\hline
\end{tabular}

A great number of informal words proves the fact that despite the formality and standards, political communication is characterized by expressiveness. Neologisms draw a reader's attention to new political realia and reflect journalists' creativity. Euphemisms veil unpopular political actions.

\section{Stylistic peculiarities of Americal political news}

Speaking about stylistic peculiarities we divided them into tropes (metaphors, metonymies, epithets), syntactical stylistic devices (repetitions, antithesis, rhetorical questions), phraseological units. We should say that the US political news abounds in political metaphors. Politicians use figurative language to control public consciousness particularly during the political and economic crises when they are trying to persuade the society to do and believe such things they would neither believe nor do otherwise ${ }^{9}$. The metaphor "Politics=theatre/circus" conceptualizes politics on the basis of associations of politics and theatrical or circus action ${ }^{10}$. Politicians are like actors, directors, puppets (political actor/director/clown/puppet), who take part in a show (political play/show), doing something (to play/act/perform), and using certain attributes (mask/puppet) on the stage (political stage/arena) for some purpose (triumph/success):

...Trump: "Clown" Obama "The Biggest Liar I Know" ... This willingness to tease Washington had made some wary of the role Cuba might play in the contemporary geopolitics [CNN News].

...multiple geopolitical audiences, wearing a Western mask to Western leaders [CNN News].

Speaking about Melania Trump's departure from the White House, the journalists compare metaphorically her marriage with gig: ...Certainly many - particularly those who have long fantasized that Melania Trump was a

${ }^{9}$ Chilton P., Ilyin M. Metaphor in political discourse: the case of the "Common European House". Discourse and Society. London : Sage, 1993. Vol. 4. Issue 1. P. 7-31. DOI: 10.1177/0957926593004001002.

${ }^{10}$ De Landtsheer Ch., Feldman O. Beyond speech and symbols: Explorations in the rhetoric of politicians and the media. Westport, CT : Praeger, 2000. P. 35-51. 
victim to be freed - would like to see her jump the Trump ship, now that the gig is finished [CNN News]. It is worth mentioning that in American English the word gig means "a piece of work that you do for money".

Let us give the example of the other political metaphor: ...Donald Trump's toolbox has never held anything but hammers, so it is no surprise that he used one of them - blunt character assassination - against Ambassador Marie Yovanovitch [CNN News]. Trump's policy is compared to a hammer, that is, the President's rudeness, undiplomatism, and sharpness are emphasized.

Touching upon Biden's first staff appointments including five women and four people of color the journalists use the following metaphor: ...An all-white, all-male Cabinet is, I hope, in the dustbin of history [CNN News].

Metaphor in political discourse enhances the pragmatic potential of the text, emphasizes its semantic and emotional unity ${ }^{11}$.

Among other tropes, metonymy, a trope built on the transfer of meaning by contiguity, is also used in political texts e. g.: ...The White House did not respond to repeated requests for comment to a series of questions regarding the meeting and Trump's relationship with Parnas and Fruman [CNN News].

"I told Turkey if they do anything outside of what we think is humane ... they could suffer the wrath of an extremely decimated economy", the President said [CNN News].

There are the examples of comparison in American political news: "You're tough as nails and you're smart as hell", the retiring Texas Republican told Yovanovitch during his period of questioning [CNN News].

...Trump touted Tillerson as the crown jewel of his Cabinet - a hugely successful and accomplished businessman that only this President could recruit to work for the government [CNN News].

...GOP congressman to former ambassador: "You're tough as nails and smart as hell", the retiring Texas Republican told Yovanovitch during his period of questioning [CNN News].

Epithets are very important for political discourse. The epithet used by a politician, positive or disapproving, sometimes determines the outcome of his manipulation of people. Since epithets are widely used in political news, they serve not only as a powerful means of assessment but they also perform the regulative function, imposing on the recipient the ideological and axiological views of the addresser concerning the object of assessment, and

11 Чудинов А.П. Очерки по современной политической метафорологии : монография. Екатеринбург, 2013. 176 с. 
ultimately, making him change his mind in favour of the manipulator ${ }^{12}$. We investigated that negative epithets prevail:

...Maybe this was the One where all would decide that they wanted impeachment, that the president's behavior was so outrageous that they couldn't imagine this sleazy business guy sitting in the Oval Office playing a tinpot dictator in a tinfoil hat for another second [CNN News].

...Their draconian actions were so contrary to American values and law that at least one whistleblower felt they could not morally or legally carry out their orders [CNN News].

Epithets with negative connotation are widely used to describe the recent elections in the USA: ...The two made history on November 7 when they beat Trump in a bitter election that put him in a small club of presidents who served only one term [CNN News].

...Dozens of judges - some appointed by Trump - have summarily dismissed his ferocious assault on the election results [CNN News].

...If it were occurring anywhere else, Americans would condemn it as an appalling attempt to undermine democracy [CNN News].

Thus, those epithets reflect a political assessment and a speaker's stand.

Syntactical stylistic device, repetition, is widely used in political texts: ...We have more work to do. More work to do for the workers I met in Galesburg [CNN News]. Repetition makes you listen to what the speaker is saying and attracts the audience's attention. There are also many repetitions in Trump's speeches: ...You're read - let me just tell you, I have the real polls. I have the real polls. The CNN polls are fake [CNN News].

Antithesis is a stylistic device built on the emphasized opposition of opposite phenomena, concepts, opinions. The antithesis is based on the antonymous pair: "And they're "elite", but we're not elite", Trump said tonight [CNN News]. That device is typical for Trump, who bases his entire policy on the confrontations: Americans vs. non-Americans, the White vs. the Black etc.

Rhetorical questions are also common for politicians' speeches. With their help politicians express their emotions and skillfully activate the audience's attention: ... Will we better off if we depend less on foreign oil and more on our own ingenuity? [CNN News]. One cannot ignore such a stylistic device as gradation. Gradation is a stylistic figure of a certain structure, in which each subsequent part enhances the semantic or emotional-expressive meaning: ...if one voice can change a room, then it can change a city, and if it can change a city, it can change a state, and if it changes a state, it can change a nation, and if it can change a nation, it can

12 Шустова И.Н. Функция эпитетов в американском политическом дискурсе. Russian linguistic bulletin. 2016. № 2(6). P. 33-34. DOI: 10.18454/RULB.6.07. 
change the world. Your voice can change the world [CNN News]. A speaker gradually brings us to the main thing, thus facilitating perception of speech, which leads to an immediate reaction of a recipient.

One of the most significant peculiarities of American political news are phraseological units. The American politicians often use them to provide emotional and expressive community of the speaker and the audience.

According to Kunin's classification, we divided phraseological units from American political news into following groups ${ }^{13}$ :

1) nominative:

...Zakaria on Syria: Trump revealing he is a paper tiger [CNN News]. The idiom paper tiger means "a safe rival". Its content is formed being based on combination of contradictory concepts - paper and tiger.

The idiom out of thin means "to appear suddenly". The idiom a witch hunt has historical roots. The phrase is now used to investigate the alleged illegal activities of a group of people who have a different view of a situation, whose position differs from that of the majority: ...Trump has continuously tweeted arguments in his own defense and lashed out at Democrats about the probe, calling it a "witch hunt" [CNN News].

The idiom on the heels has a meaning "following closely after": ...Consumer sentiment rebounded sharply - and surprisingly - in December on the heels of Joe Biden's election win, which outweighed worries about the coronavirus pandemic [CNN News].

Some nominative idioms are derived from verbal ones: It is unlikely to be a rock-the-boat selection like leftwing Massachusetts senator Elizabeth Warren, who would probably spark anxiety among the business community, or someone like JP Morgan's chief executive, Jamie Dimon, a hypothetical candidate who would infuriate progressives [CNN News]. The idiom $\boldsymbol{a}$ rock-the-boat selection is originated from a phraseological unit to rock a boat that means "to do or say something that changes a situation in a way that causes problems".

It is worth saying that nominative phraseological units are not as frequent in American political news as verbal, probably because politics is primarily an action verbalized by verbs.

2) verbal:

...He urged Biden, over and over, to "pass the torch" to a new generation of Democrats [CNN News]. The idiom to pass the torch comes from sports, in a figurative sense, it has the interpretation "to pass the work which he worked on before" (pass the baton). When, on the contrary, a person takes the baton from someone, they say to take the baton: ...And tried

13 Кунин А.В. Курс фразеологии современного английского языка. Дубна : Феникс+, 2005. 488 с. 
to take the baton and run the race a little further, and then I expect people to take the baton from me and then I want them to run it a little further from that [CNN News].

...Longtime Trump political adviser Roger Stone was found guilty on Friday of lying to and obstructing Congress in a case that has shed new light on President Donald Trump's anticipation of the release of stolen Democratic emails in 2016 by WikiLeaks [CNN News]. The idiom shed new light means "to clarify the situation".

The idiom to work my tail off means "to work hard": ...Obama's comments are particularly noteworthy because he rarely comments on the Democratic field, aside from - as he did on Friday - promising to "work my tail off to make sure" whoever wins the nomination defeats President Donald Trump [CNN News].

The next idiom undermines Trump's authority: ...At the same time, the Republicans who did follow Donald Trump really have an obligation now to make the country strong again, to heal the chinks that Donald Trump tried to put in the foundation and the democracy [CNN News].

Some tough idioms can be found in description of Trump's behavior due to the election results: ...the court's unsigned order was "the closest possible thing to the last nail in the coffin for election-related legal challenges" [CNN News]. If you say that an event is the last nail or the final nail in the coffin of something or someone, you mean that it finally destroys something or causes someone to fail.

There some cases when two idioms are used within one sentence: ...Trump's presidency "is off the rails", Zelizer wrote, "and he is playing with a fire of racism, nativism and social division" [CNN News].

The use of phraseological units in the US political news makes it possible to solve one of the main tasks - to combine the maximum level of informativeness with the expressive and emotional content of the material. Undoubtedly, phraseological units give an emotional color to a political text, express an assessment of a particular policy or event, and to some extent depend on the language competence of an addressee. Table 2 presents frequency of functioning stylistic peculiarities in American political news.

Table 2

Stylistic peculiarities of American political news and their quantative indicators

\begin{tabular}{|c|c|}
\hline Stylistic peculiarities & Quantitative indicators \\
\hline Tropes & $38 \%$ \\
\hline Syntactical stylistic devices & $30 \%$ \\
\hline Phraseological units & $32 \%$ \\
\hline
\end{tabular}


As table 2 shows tropes are the most frequent stylistic peculiarities in the US political news. We should note that all stylistic means actively function in political communication, give expressiveness, attract a reader's attention and influence his opinion. There is a high frequency of metaphors in political news, due to the fact that metaphor has become one of the strongest means of presenting political concepts and having an influence on the political consciousness of society.

To sum it up, stylistic means in political news do not complicate the understanding of what is being said, but, on the contrary, contribute to it. With the help of them politicians influence the consciousness of the audience, both implicitly and explicitly. The intentions of politicians are to build effectively communication that promotes mutual understanding and trust on the part of recipients.

All the linguistic and stylistic peculiarities features of US political news considered by us, have some influence on the communicative features of the studied discourse. Among communicative features of American political texts we can single out simplicity, informativeness, expressiveness, manipulativeness:

1) simplicity is the use of common vocabulary, colloquial vocabulary and colloquialisms, abbreviations;

2) informativeness is achieved using proper names, quantitative indicators, dates, place names, realia;

3) expressiveness of American political texts is provided with the help of expressive and evaluative vocabulary, metaphors, idioms;

4) manipulativeness is achieved with the help of euphemisms, quantitative indicators, inclusive pronouns.

\section{CONCLUSIONS}

Summing up our paper, we can conclude that all practical examples indicate that the US political news represents a multidimensional linguistic phenomenon. It can be explained by the fact that political discourse implies a variety of communicative strategies, a high degree of argumentation to defend one's point of view, to justify, or to approve the audience. Verbal components of political discourse have an impact on the recipients' consciousness and can take the form of political manipulation.

The period of 2019-2020 years was significant for the US politics. It is necessary to stress that American news has five thematic clusters: impeachment of the President, the USA foreign policy, struggle against migrants, elections, COVID-19. They represent the most topical issues for American politics and society. That's why they are verbalized by a great number of lexical units which have positive and negative connotation.

Those thematic clusters abound in lexical and stylistic peculiarities which are connected with communicative functions of political discourse: lexical 
innovations, juridical terms perform the function of informativeness; euphemisms help the politicians to manipulate the audience; Americanisms, informal words, metaphors, phraseological units are used for emotional and expressive coloring and evaluation of politicians.

On the stylistic level the most relevant peculiarities of American political news are stylistic tropes (metaphor, metonymy, epithets), syntactical stylistic devices (repetitions, gradation, antithesis, rhetoric questions), phraseological units. We sorted out the nominative and verbal phraseological units. We can conclude that the verbal phraseological units prevail and they are mainly related to D. Trump.

There is a high frequency of metaphors in political discourse, due to the fact that metaphor has become one of the strongest means of presenting political concepts and having an influence on the political consciousness of society. The study showed that the more charismatic politician the more stylistic and lexical means he uses in his speeches or journalists use speaking about him.

These findings suggest the following directions for future research: the translation techniques for lexical innovations in American political discourse into the Ukrainian language.

\section{SUMMARY}

The paper examines the linguistic and stylistic features of the US political news during 2019-2020 years. The peculiarity of American political news is made up of various lexical, semantic and stylistic features, among which we highlighted: juridical terms, colloquial vocabulary, euphemisms, neologisms, Americanisms. Among the stylistic features we distinguished tropes (metaphors, metonymy, epithets), syntactical stylistic devices (repetitions, gradation, antithesis, rhetorical questions), phraseological units. Political news has a high frequency of political metaphors.

We sorted out the most relevant thematic groups of Americal political news and studied their verbalization: elections, COVID-19, the USA foreign policy, struggle against migrants, the impeachment of $\mathrm{D}$. Trump.

Communicative peculiarities of American political texts which are simplicity, informativeness, expressiveness, manipulativeness were examined through the prism of linguistic and stylistic features.

\section{REFERENCES}

1. Dijk T. Discourse and manipulation. Discourse and society. London : SAGE Publications, 2006. P. 359-383. DOI: 10.1177/0957926506060250.

2. Chilton P. Politics as Text and Talk: Analytic Approaches to Political Discourse. Discourse Approaches to Politics, Society and Culture. Amsterdam, 2002. P. 123-132. DOI: 10.1075/dapsac.4. 
3. Charteris-Black J. Politicians and rhetoric: the persuasive power of metaphor. New York : Palgrave McMillan, 2005. 256 p. DOI: $10.1057 / 9780230501706$.

4. Зацний Ю.А. Способи та механізми створення лексикофразеологічних інновацій англійської мови (2009-2019 рр.). Нова філологія. Запоріжжя : ЗНУ, 2020. № 79. С. 20-26. DOI: 10.26661/24141135/2020-79-04.

5. Holder R.W. Dictionary of euphemisms. Oxford : Oxford University Press, 2008. $501 \mathrm{p}$.

6. Mosiyevych L. The Formation of a Modern Translation Competence in Translator Training. At the Crossroads: Challenges of Foreign Language Learning. 2017. April. P. 189-203. DOI: 10.1007/978-3-319-55155-5.

7. Зацний Ю.А. Сучасний англомовний світ i збагачення словникового складу. Львів : ПАІС, 2007. 228 с.

8. Ларцева Е.В. Современный статус американского варианта английского языка и перспективы его развития. Актуальные проблемы германистики, романистики и русистики : материалы ежегодной международной конференции, г. Екатеринбург, 3-4 февраля 2012 г. : в 2 ч. Екатеринбург, 2012. Ч. 1. С. 83-90.

9. Chilton P., Ilyin M. Metaphor in political discourse: the case of the "Common European House". Discourse and Society. London : Sage, 1993. Vol. 4. Issue 1. P. 7-31. DOI: 10.1177/0957926593004001002.

10. De Landtsheer Ch., Feldman O. Beyond speech and symbols: Explorations in the rhetoric of politicians and the media. Westport, CT : Praeger, 2000. $312 \mathrm{p}$.

11. Чудинов А.П. Очерки по современной политической метафорологии : монография. Екатеринбург, 2013. 176 с.

12. Шустова И.Н. Функция эпитетов в американском политическом дискурсе. Russian linguistic bulletin. 2016. № 2(6). Р. 33-34. DOI: 10.18454/RULB.6.07.

13. Кунин А.В. Курс фразеологии современного английского языка. Дубна : Феникс+, 2005. 488 с.

\section{Information about the author:} Mosiyevych L. V.,

Candidate of Philological Sciences, Associate Professor, Associate Professor at the Department of General Education Institute of Education and Science in Engineering of the Zaporizhzhia National University 226, Soborny avenue, Zaporizhzhia, 69120, Ukraine 